\title{
Comparison of Definitive Radiotherapy in the Young-Elderly and Elderly with Clinical Localized Prostate Cancer
}

\author{
Klinik Lokalize Prostat Kanserli Genç Yaşlı ve Yaşlı Hastalarda Küratif Radyoterapinin \\ Karşılaştırılması
}

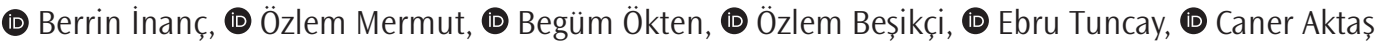

University of Health Sciences Turkey, İstanbul Training and Research Hospital, Clinic of Radiation Oncology, İstanbul, Turkey

\begin{abstract}
Introduction: This study aimed to investigate the survival, treatment-related toxicities, and prognostic factors in the elderly $(\geq 65)$ with prostate cancer treated with definitive radiotherapy (RT). Patients divided into two groups as youngold (65-74 years) and old (over 75 years) were examined.

Methods: A total of 178 patients with prostate cancer treated with definitive RT were retrospectively reviewed. The prognostic factors for survival, metastasis-free survival (MFS), biochemical recurrence-free survival (BFS), and treatment-related toxicities were analyzed.
\end{abstract}

Results: Pretreatment prostate-specific antigen (PSA), last PSA value, and Charlson comorbidity score (5-6) were significantly different between the two groups $(p=0.001, p=0.004$, and $p=0.012$, respectively). The elderly showed high pretreatment PSA, last PSA value, and Charlson comorbidity score (5-6). None of the other treatment or patient characteristics differed significantly between the groups. The median follow-up time was 68 months (range: 12-116 months) for the young-elderly. The 5-year overall survival (OS), BFS, and MFS were $86.4 \%$, $91.5 \%$, and $92.8 \%$, respectively, in the young-elderly. Median follow-up time in the elderly patients was 60 months (range: 7-118 months) and 5-year OS, MFS, and BFS rates were $79.6 \%$, $93.1 \%$, and $93.4 \%$, respectively. No statistical difference was found when the OS, BFS, and MFS were evaluated in 5 years in both groups. The multivariate analysis revealed that high radiation doses (76 Gy and $\geq 78 \mathrm{~Gy}$ ) and high T-stage (T3-4) was a significant prognostic factor for the BFS in all patients ( $p=0.013, p=0.007$, and $p=0.026$, respectively). The presence of high-risk patients in the risk stratification was borderline significant for the BFS $(p=0.051)$. Acute hematological toxicity, such as leucopenia (38\%), and late toxicity, such as rectal bleeding (10\%), were frequently observed in the elderly.

Conclusion: No differences were found in the OS, BFS, and MFS between the two groups. High radiation doses and high T-stage was found as a prognostic factor for the BFS in all patients.

Keywords: Radiotherapy, aged, survival

\section{öZ}

Amaç: Bu çalışmada, küratif radyoterapi ile tedavi edilen yașlı (65 yaş ve üzeri) prostat kanserli hastaların sağkalımları, tedaviye bağlı toksisiteleri ve prognostik faktörlerini araștırmayı amaçladık. Hastaları, genç yaşı ı (65-74 yaş) ve yaşlı (75 yaș üstü) olarak iki grupta inceledik.

Yöntemler: Toplam 178 prostat kanseri hastası retrospektif olarak inceledik. Genel sağkalım, metastazsız sağkalım, biyokimyasal rekürrenssiz sağkalım (BFS), tedaviye bağlı toksisiteler ve bu sonuçlara etki eden prognostik faktörler analiz edildi.

Bulgular: Tedavi öncesi PSA, son PSA değeri ve Charlson comorbidite skoru yaşı ı ve genç yașlı hastalar arasında istatistiksel farklı bulundu $(p=0,001, p=0,004$ ve $p=0,012)$. Yaşlı grupta, tedavi öncesi PSA değeri, son PSA değeri ve Charlson comorbidite skoru (5-6) yüksekti. Her iki grup arasında, diğer tedavi ve hasta özelliklerinden hiçbiri istatiksel olarak anlamlı bulunmadı. Ortanca takip süresi genç yaşlılar için 68 aydı (aralık: 12-116 ay). Genç yaşlı hastalarda 5 yıllık genel sağkalım (OS), BFS ve metastazsız sağkalım (MFS) \%86,4, \%91,5 ve \%92,8 idi. Yașlı hastalarda ortanca takip süresi 60 ay (aralık: 7-118 ay) ve 5 yıllık OS, MFS ve BFS oranları sırasıyla $\% 79,6, \% 93,1$ ve \%93,4 idi. Her iki grupta da 5 yıllık OS, BFS ve MFS arasında fark bulunmadı. Çok değișkenli analizde, yüksek radyasyon dozları (76 Gy ve $\geq 78$ Gy), ileri T-evresi (T3-4) tüm hastalarda BFS için anlamlı bir prognostik olarak bulundu (sırasıyla; $p=0,013$, $p=0,007$ ve $p=0,026$ ). Ayrıca risk sınıflandırmasında yüksek riskli hastalık BFS için sınırda anlamlı bulundu $(p=0,051)$. Yaşlı hastalarda, akut hematolojik toksisite olarak lökopeni (\%38) ve geç toksisite olarak rektal kanama (\%10) daha sık izlendi.

Sonuç: Genç yaşlı ve yaşlı hastalarda genel sağkalım, BFS ve metastazsız sağkalım açısından bir fark bulunmadı. Tüm hastalarda BFS için yüksek radyasyon dozları ve yüksek T-evresi prognostik faktördü.

Anahtar Kelimeler: Radyoterapi, yașlı, sağkalım 
Inanç et al. Curative Prostate Radiotherapy in Elderly Patients

\section{Introduction}

Prostate cancer has become one of the most frequently diagnosed cancers today as a result of prolonged life expectancy (1). The majority of patients with prostate cancer are over 75 years old at the time of diagnosis and this rate increases even more in developed countries due to their life expectancy prolongation (2). Older patients are more likely to have a more aggressive form of the disease at the time of diagnosis. Moreover, it is a heterogeneous group in terms of treatment response rates. Prostate cancer in the elderly that is mostly treated with active surveillance, watchful waiting, androgen deprivation therapy (ADT) and/or radiotherapy (RT), and prostatectomy is rarely recommended (3). Patients may have one or more of these treatments together.

The elderly is unclearly defined, and the minimum age for classifying the elderly ranges from 65 to 70 years. Some studies subdivided the older patients into "younger old" (65-74 years old) and "older" (75-84 years) (4), whereas our study categorized 65-74 years old as younger old and 75 years old and over as an elderly group and compared both groups. Therefore, this study aimed to investigate prognostic factors, treatment outcomes, survival, and toxicity in both groups of patients with prostate cancer treated with RT. In addition, the prognostic risk factors affecting the overall survival (OS), metastasis-free survival (MFS), and biochemical recurrence-free survival (BFS) were investigated in these patients.

\section{Methods}

\section{Eligibility Criteria}

This retrospective study analyzed the demographic outcomes, treatment outcomes, and toxicity data in a single-center cohort of 178 patients who received RT for prostate cancer between January 2012 and December 2018. The patients were divided into two groups: young-older (65-74) and older ( $\geq 75$ years). Patients with clinically (T1-4 and N0M0) TNM stage (5) and histologically proven adenocarcinoma, who received RT treatment, with pretreatment prostate-specific antigen (baseline PSA) levels and total Gleason scores (GS), were evaluated. Patients with distant metastases at baseline and under 65 years old were excluded.

Patients were categorized using the National Comprehensive Cancer Network (NCCN) 2020 risk stratification as follows: low, T1-T2a, GS of 2-6, and PSA of $<10 \mathrm{ng} / \mathrm{mL}$; medium, T2b-T2c, GS of 7, or PSA of 10-20 ng/ $\mathrm{mL}$; and high, T3a-T4, GS of 8-10, or PSA of $>20 \mathrm{ng} / \mathrm{mL}$ (6). PSA deficiency was defined using the Phoenix definition (rare, $+2 \mathrm{ng} / \mathrm{mL}$ ).

The study was approved by the Human Research Ethics Committee of the University of Health Sciences Turkey, İstanbul Training and Research Hospital (approval number: 2782, date: 9.03.2021) according to the Declaration of Helsinki. Informed consent was obtained from all patients after a thorough explanation of the study. All related laboratory and pathology results were obtained from the hospital data, and data related to the treatment follow-up were obtained from the clinical files.

\section{Radiotherapy Data}

All patients were diagnosed with a biopsy before the treatment. Definitive RT was applied as intensity-modulated therapy or volumetric modulated arc therapy. External beam RT was administered at 1.8-2.0
Gy daily fractions with 6 MV photon beams, 5 days a week. The pelvic region was added to the RT area in patients with pelvic lymph node involvement and those with $>15 \%$ risk of lymph node involvement according to the Roach formula (7). A total dose of 46 Gy was given to the pelvic region, 54 Gy to the seminal vesicle (SV), and 76-78 Gy to the prostate. Gross tumor volume included the primary prostate. The clinical target volume was defined as pelvic lymph nodes (CTV3), SV + prostate (CTV2), and prostate only (CTV1). The planning treatment volume was defined as a pelvic lymph node margin of $0.7 \mathrm{~mm}$. CTV2 and CTV1 were defined as $8 \mathrm{~mm}$ in all directions and $5 \mathrm{~mm}$ in the posterior direction. Local RT (prostate only) was applied to patients in the intermediate and low-risk groups according to the NCCN risk stratification.

\section{Outcomes and Follow-Up}

The BFS, MFS, and OS rates were examined in each patient group treated with these two treatment modalities. BFS, MFS, and OS were defined as the time from RP/RT until the biochemical failure, metastasis, and death of any cause, respectively.

Treatment toxicity was evaluated using the Common Terminology Criteria for Adverse Events version 4.0 (8). During RT, patients were assessed at least once a week with a clinical examination and blood counts analyses. After RT, the patients' PSA levels were checked every 3 months in the first 2 years and abdominal/pelvic tomography and bone scanning were performed every 6 months. Follow-up was done every 6 months for 2-5 years, and once a year after 5 years. During the followup period, prostate-specific membrane antigen positron emission tomography/computed tomography and multiparametric magnetic resonance examination were requested in patients with suspected local or regional recurrence and distant metastasis.

\section{Statistical Analysis}

The mean, standard deviation, and median values were used in presenting descriptive analyzes. Categorical variables were compared using the Fisher's exact test and the Mann-Whitney $U$ test to evaluate non-parametric variables between the two groups. BFS, MFS, and OS were evaluated using the Kaplan-Meier analysis. The univariate and multivariate Cox regression analysis was used to evaluate interactions between the two groups and prognostic variables for BFS outcome. All analyses were performed at a 95\% confidence level with a 0.05 significance level using the Statistical Package for the Social Sciences 17.0 (SPSS Inc., Chicago, IL, USA) for the windows program.

\section{Results}

Retrospective data, available treatment features, and survival records of 178 patients diagnosed with prostate cancer and treated with RT were analyzed. Table 1 presents some baseline characteristics of the patients and their treatments. Pretreatment PSA, last PSA value, and Charlson comorbidity score were significantly different between the older and young-older groups ( $p=0.001, p=0.004$, and $p=0.012$, respectively). The older group showed high pretreatment PSA value, last PSA value, and Charlson comorbidity score (5-6). ADT was used as a neoadjuvant for 6 months for a total of 2-3 years in patients with high risk. In the youngelderly, long ADT (2-3 years) was used in 54 (47\%) patients and short ADT 


\section{Table 1. Comparison of patient characteristics according to age groups}

\begin{tabular}{|c|c|c|c|c|}
\hline \multirow[b]{2}{*}{ Variables } & \multirow[b]{2}{*}{ Strata } & \multirow{2}{*}{$\begin{array}{l}\text { Younger older (65-74 year) } \\
(n=115)(64.5 \%)\end{array}$} & \multirow{2}{*}{$\begin{array}{l}\text { Older ( } \geq 75 \text { year) } \\
(n=63)(35.5 \%)\end{array}$} & \multirow{2}{*}{ p } \\
\hline & & & & \\
\hline Age & Mean & 69.21 & 76.52 & 0.885 \\
\hline \multirow[t]{2}{*}{ T-stage } & $1-2$ & $111(96 \%)$ & $62(98 \%)$ & - \\
\hline & $3-4$ & $108(4 \%)$ & $5(2 \%)$ & $0.296^{\mathrm{a}}$ \\
\hline \multirow[t]{2}{*}{ Risk category } & High & $57(49.6 \%)$ & $32(50.8 \%)$ & - \\
\hline & Low-intermediate & $58(49.4 \%)$ & 31 (48.2\%) & $0.292^{\mathrm{a}}$ \\
\hline \multirow[t]{2}{*}{ RT doses } & $\geq 78 \mathrm{~Gy}$ & $40(34.8 \%)$ & $22(34.9 \%)$ & - \\
\hline & $\leq 74 \mathrm{~Gy}$ and $76 \mathrm{~Gy}$ & 75 (65.2\%) & 41 (65.1\%) & $0.521^{a}$ \\
\hline \multirow[t]{2}{*}{ Charlson comorbidity score } & $2-4$ & 77 (66.9\%) & $21(31 \%)$ & - \\
\hline & $5-6$ & 38 (33.1\%) & $42(66.6 \%)$ & $0.012^{\mathrm{a}}$ \\
\hline \multirow[t]{2}{*}{ Treatment modalities } & IMRT & 45 (39.1\%) & $36(57.1 \%)$ & - \\
\hline & VMAT & 70 (60.9\%) & $27(42.8 \%)$ & $0.428^{\mathrm{a}}$ \\
\hline Follow-up & - & $68(12-116)$ & $60(7-118)$ & - \\
\hline Exitus & - & $28(24.3 \%)$ & 22 (34.9\%) & $0.570^{\mathrm{a}}$ \\
\hline
\end{tabular}

(6 months) in 54 (43.5\%). In the elderly, long ADT was used in 31 (49.2\%) patients and short ADT in 24 (38.1\%). None of the other treatment or patient characteristics significantly differed between the groups.

Table 2 presents the treatment side effects according to age group. Acute hematological toxicity, such as leucopenia in 24 (38\%) patients, was observed more frequently in the elderly $(p=0.005)$. Non-hematological toxicity, such as diarrhea and proctitis, was observed in both age groups, without differences in the rates of these side effects between the groups $(p \geq 0.005)$. Common late complications include rectal bleeding (10\%) and fistula (4\%) in the elderly. Rectal bleeding was statistically significant and more common in the elderly $(\mathrm{p}=0.003)$. Grade- 3 and higher late complications occurred in two elderly (3\%) and one young-elderly (1\%). No grade 4 or 5 toxicity complications were found in either group.

At a median follow-up of 68 months (range: 12-116 months), 28 (24.3\%) young-older patients were exitus, whereas 22 (34.9\%) older patients were exitus at 60 months (range: 7-118 months). Biochemical recurrence was detected in nine patients and distant metastasis in eight patients in the young-older patient group, whereas 5 and 4 patients in the older patient group, respectively. The Kaplan-Meier analysis evaluated the BFS, MFS, and OS time (Figure 1). The 5-year BFS were 91.5\% (young-older) and 93.4\% (older). The 5-year MFS was 92.8\% (young-older) and 93.1\% (older). The 5-year OS were $86.4 \%$ (young-older) and 79.6\% (older). No statistical difference was found in the BFS, MFS, and OS values in both groups.

No prognostic factors were found to affect the survival in univariate and multivariate cox regression analyzes for OS and MFS ( $p \geq 0.005)$. The multivariate Cox regression analysis for BFS (Table 3) found the RT dose of $76 \mathrm{~Gy}$ and $78 \mathrm{~Gy}$ as independent prognostic factors compared to 74
Gy $(p=0.013$ and $p=0.007)$. According to the NCCN risk classification, the high risk of patients was observed as a borderline significant independent prognostic factor for BFS ( $p=0.051)$. In addition, high T-stage (T3-T4) was a prognostic factor for BFS in multivariate analysis $(p=0.026)$.

\section{Discussion}

Age is one of the important factors influencing the treatment choice for clinicians. ADT was previously considered as a standard treatment in the elderly with prostate cancer. Since the 2000s, notable advances in technology, such as increased laparoscopic surgery, hypofractionation, and new RT techniques, were used in the elderly, and the use of ADT ceased to be standard. In addition, the International Association of Geriatric Oncology has recommended that healthy or fit elderly patients be treated like younger patients (9).

By 2030, 70\% of all cancers are estimated to occur in patients aged 65 years and over (10). Old age is defined in many ways. Some articles take 70 years and above as the threshold value as elderly, whereas above 75 years in some studies (11). Our study compared the treatment results, treatment-related toxicity, and prognostic factors of patients with prostate cancer aged 65-74 years (young-old) and aged 75 years and over (old).

Tumor stage, GS, and initial PSA value are the most known prognostic factors for prostate cancer. In our study, the initial PSA value and the last PSA value were found to be higher $(21.05 \mathrm{ng} / \mathrm{dL}$ vs $32.42 \mathrm{ng} / \mathrm{dL}$ and $0.9 \mathrm{ng} / \mathrm{dL}$ vs $4.5 \mathrm{ng} / \mathrm{dL}$, respectively) in the elderly group and was statistically significant $(p=0.001$ and $p=0.004)$, confirming that prostate cancer progresses more aggressively in older ages. Charlson comorbidity 
Table 2. Acute and late toxicities according to age groups

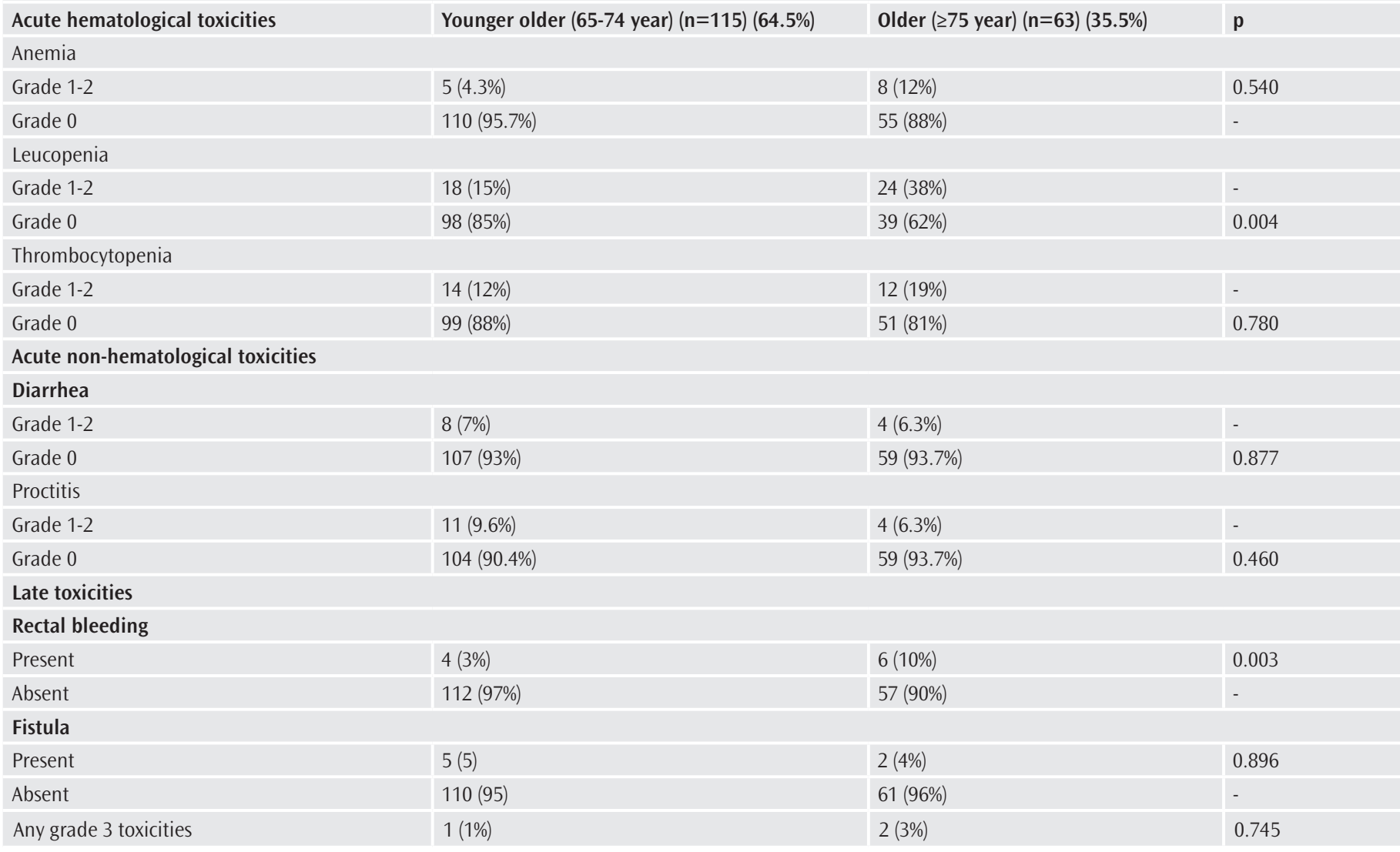

Table 3. Univariate and multivariate analysis for the BFS

\begin{tabular}{|c|c|c|c|c|c|}
\hline & & Univariate $\mathrm{HR}(95 \% \mathrm{Cl})$ & $\mathrm{p}$ & Multivariate $\mathrm{HR}(95 \% \mathrm{Cl})$ & $\mathrm{p}$ \\
\hline Variables & Strata & - & - & - & - \\
\hline Age & (65-74 vs $\geq 75)$ & $0.412(0.244-1.011)$ & 0.041 & $0.589(0.323-1.074)$ & 0.081 \\
\hline Pretreatment PSA & $\mathrm{Ng} / \mathrm{dL}$ & $1.010(0.996-1.024)$ & 0.192 & - & - \\
\hline T-stage & T1-2 vs T3-4 & $0.546(0.444-1.200)$ & 0.032 & $0.642(0.356-1.089)$ & 0.026 \\
\hline \multirow[t]{3}{*}{ Gleason score } & $\leq 6$ & 1 & - & - & - \\
\hline & 7 & $0.471(0.142-1.565)$ & 0.219 & - & - \\
\hline & $\geq 8$ & $1.284(0.270-6.102)$ & 0.754 & - & - \\
\hline \multirow[t]{3}{*}{ Risk category } & Low & 1 & - & 1 & \\
\hline & Intermediate & $0.518(0.422-1.116)$ & 0.053 & $1.887(0.608-5.849)$ & 0.272 \\
\hline & High & $0.673(0.139-3.159)$ & 0.044 & 1.199 (0.908-5.327) & 0.051 \\
\hline \multirow[t]{3}{*}{ RT doses } & $\leq 74$ Gy & 1 & & 1 & \\
\hline & $76 \mathrm{~Gy}$ & $0.671(0.679-1.943)$ & 0.081 & $1.174(0.44-0.690)$ & 0.013 \\
\hline & $\geq 78 \mathrm{~Gy}$ & $0.473(0.553-1.109)$ & 0.021 & $1.61(0.430-0.601)$ & 0.007 \\
\hline Last PSA & $\mathrm{Ng} / \mathrm{dL}$ & $0.773(0.664-6.520)$ & 0.881 & - & - \\
\hline \multirow[t]{3}{*}{ Hormonotherapy } & No & 1 & - & 1 & - \\
\hline & Short (6 months) & $0.606(0.134-2.741)$ & 0.602 & - & - \\
\hline & Long (2-3 year) & $0.451(0.131-1.556)$ & 0.208 & - & - \\
\hline Charlson comorbidity score & $2-4$ vs $5-6$ & $0.622(0.215-1.800)$ & 0.381 & - & - \\
\hline Treatment modalities & IMRT vs VMAT & $0.272(0.050-1.473)$ & 0.131 & - & - \\
\hline
\end{tabular}



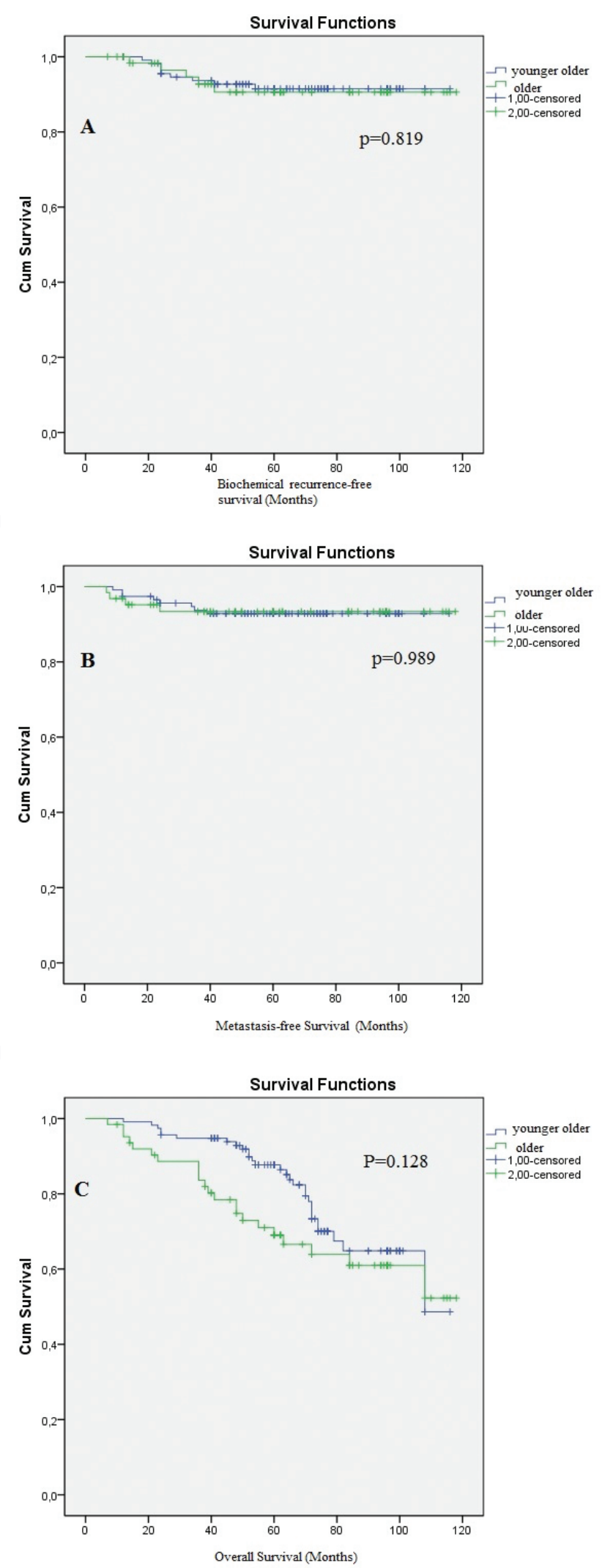

Figure 1. (A) Kaplan-Meier curve for the BFS, (B) Kaplan-Meier curve for the MFS, (C) Kaplan-Meier curve for the OS

BFS: Biochemical recurrence-free survival, MFS: Metastasis-free survival, OS: Overall survival score is a parameter used in geriatric patients, and patients are scored according to their comorbidity (12). In our study, this score was naturally found to be higher in the elderly compared to the young-elderly. No statistical differences were found between the two groups in terms of T-stage, GS, NCCN risk categories, use of adjuvant or neoadjuvant ADT, RT dosage, and RT techniques ( $p>0.005)$.

No prognostic factors were found to affect the survival in univariate and multivariate cox regression analyzes for OS and MFS. High RT dosage for BFS was found to be a prognostic factor in univariate and multivariate analyzes. Many randomized studies (13-16) on prostate cancer observed that increasing the RT dosage increases the BFS, but not the OS. Similarly, in our multivariate analysis for the BFS, 76 Gy and $\geq 78$ Gy RT doses were found to be an independent prognostic factor according to $74 \mathrm{~Gy}$ $(p=0.013$ and $p=0.007)$. This result was consistent with the mentioned studies. High T-stage (T3-4) was found to be a prognostic factor for the BFS compared to lower T-stage (T1-2).

Another important issue in patients with prostate cancer is the inclusion of the pelvic area in the RT field. Current guidelines suggest that pelvic irradiation should be included in the treatment area in patients with a $>15 \%$ involvement risk according to the Partin's table, clinical pelvic lymph node involvement, and high risk according to the NCCN guideline (6-7). However, pelvic RT application in the elderly increases acute toxicity and causes treatment discontinuation. Our clinic preferred to treat our patients aging $\geq 75$ years with pelvic lymph node involvement with hormonotherapy rather than RT. Side effects were found to be similar in both groups since pelvic irradiation was preferred in younger patients. Among the acute hematological side effects, leukopenia (grades 1-2) and rectal bleeding (grades 1-2), among the late side effects, were more common in the elderly ( $p=0.004$ and $p=0.003$, respectively).

\section{Study Limitations}

Our study had some limitations. First, the patients' quality of life after RT was not assessed. Second, the use of ADT increases the risk of fractures (17) and is associated with diabetes (18) and cardiovascular morbidity (19), requiring care, especially in the elderly. Side effects of ADT use in the elderly were not studied. Third, the elderly were in the higher risk category, and those receiving active surveillance and wait-and-see treatment were not included in the study.

\section{Conclusion}

According to our study results and literature findings, treatment outcomes, including survival times, are similar in the young-elderly and elderly. Based on the subgroup analyses, pretreatment PSA, last PSA, and Charlson comorbidity score treatment toxicities are higher in the elderly. RT dosage escalation was found to be the most important prognostic factor for all patients.

Ethics Committee Approval: The study was approved by the Human Research Ethics Committee of the University of Health Sciences Turkey, İstanbul Training and Research Hospital (approval number: 2782, date: 9.03.2021) according to the Declaration of Helsinki. 
Informed Consent: Informed consent was obtained from all patients after a thorough explanation of the study.

Peer-review: Externally and internally peer-reviewed.

Authorship Contributions: Concept - Ö.M., B.Ö., C.A.; Design - B.I., Ö.M., Ö.B.; Data Collection or Processing - B.I.., B.Ö., Ö.B., E.T., C.A.; Analysis or Interpretation - B.I., B.Ö., E.T., C.A.; Literature Search - Ö.M., Ö.B., E.T., C.A.; Writing - B.I., Ö.M.

Conflict of Interest: No conflict of interest was declared by the authors.

Financial Disclosure: The authors declared that this study received no financial support.

\section{References}

1. Bray F, Ferlay J, Soerjomataram I, Siegel RL, Torre LA, Jemal A. Global cancer statistics 2018: GLOBOCAN estimates of incidence and mortality worldwide for 36 cancers in 185 countries. CA Cancer J Clin 2018; 68: 394-424.

2. Bechis SK, Carroll PR, Cooperberg MR. Impact of age at diagnosis on prostate cancer treatment and survival. J Clin Oncol 2011; 29: 235-41.

3. Bekelman JE, Mitra N, Handorf EA, Uzzo RG, Hahn SA, Polsky D, et al. Effectiveness of androgen-deprivation therapy and radiotherapy for older men with locally advanced prostate cancer. J Clin Oncol 2015; 33: 716-22.

4. Kennedy BJ. Aging and cancer. J Clin Oncol 1988; 6: 1903-11.

5. National Comprehensive Cancer Network. NCCN Clinacal Practice Guidelines in Oncology; Prostate Cancer 2020 Version 2; National Comprehensive Cancer Network: Fort Washington, PA, USA; 2016.

6. Partin AW, Mangold LA, Lamm DM, Walsh PC, Epstein JI, Pearson JP. Contemporary update of prostate cancer staging nomograms (Partin Tables) for the new millennium. Urology 2001; 58: 843-8.

7. Amiya Y, Yamada Y, Sugiura M, Sasaki M, Shima T, Suzuki N, et al. Outcomes of patients older than 75 years non-metastatic prostate cacer. Asian J Urol 2017; 4: 102-6.

8. US Department of Health and Human Services. Common Terminology Criteria for Adverse Events (CTCAE); June 14, 2010. Date last updated. Available from: http://evs.nci.nih.gov/ftp1/CTCAE/CTCAE_4.03_2010-06-14_ QuickReference_8.5x11.pdf

9. Droz JP, Aapro M, Balducci L, Boyle H, Van den Broeck T, Cathcart P, et al. Management of prostate cancer in older patients updated recommendations of a working group of the International Society of Geriatric Oncology. Lancet Oncol 2014; 15: 404-14.

10. Smith BD, Smith GL, Hurria A, Hortabagyi GN, Buchholz TA. Future of cancer incidence in the United States: burdens upon an aging, changing nation. J Clin Oncol 2009; 27: 2758-65.

11. Vellekoop A, Loeb S. More aggressive prostate cancer in elderly men. Rev Urol 2013; 15: 202-4.

12. Sundararajan V, Henderson T, Perry C, Muggivan A, Quan H, Ghali WA. New ICD-10 version of the Charlson comorbidity index predicted inhospital mortality. J Clin Epidemiol 2004; 57: 1288-94.

13. Zelefsky MJ, Pei X, Chou JF, Schechter M, Kollmeier M, Cox B, et al. Dose escalation for prostate cancer radiotherapy: predictors of long-term biochemical tumor control and distant metastases-free survival outcomes. Eur Urol 2011; 60: 1133-9.

14. Michalski JM, Moughan J, Purdy J, Bosch W, Bruner DW, Bahary JP, et al Effect of standard vs dose-escalated radiation therapy for patients with intermediate-risk prostate cancer: The NRG oncology RTOG 0126 randomized clinical trial. JAMA Oncol 2018; 4: e180039.

15. Beckendorf V, Guerif S, Le Prisé E, Cosset JM, Bougnoux A, Chauvet B, et al. P70 Gy versus 80 Gy in localized prostate cancer: 5-year results of GETUG 06 randomized trial. Int J Radiat Oncol Biol Phys 2011; 80: 1056-63.

16. Zietman AL, Bae K, Slater JD, Shipley WU, Efstathiou JA, Coen JJ, et al. Randomized trial comparing conventional-dose with high-dose conformal radiation therapy in early-stage adenocarcinoma of the prostate: long-term results from proton radiation oncology group/american college of radiology 95-09. J Clin Oncol 2010; 28: 1106-11.

17. Shahinian VB, Kuo YF, Freeman JL, Orihuela E, Goodwin JS. Risk of fracture after androgen deprivation for prostate cancer. N Engl J Med 2005; 352: 154 64.

18. Keating NL, O'Malley AJ, Smith MR. Diabetes and cardiovascular disease during androgen deprivation therapy for prostate cancer. J Clin Oncol 2006; 24: 4448-56.

19. D'Amico AV, Denham JW, Crook J, Chen MH, Goldhaber SZ, Lamb DS, et al. Influence of androgen suppression therapy for prostate cancer on the frequency and timing of fatal myocardial infarctions. J Clin Oncol 2007; 25: 2420-5. 